\title{
Square Kilometer
}

National Cancer Institute

\section{Source}

National Cancer Institute. Square Kilometer. NCI Thesaurus. Code C68864.

A metric unit of area equal to one million square meters (10E6 m2). One square kilometer is equal to one hundred hectares. 